\title{
Correlation between the oropharyngo-laryngoscopic findings and the severity of obstructive sleep apnea
}

\section{Correlação entre os achados orofaringolaringoscópicos e a gravidade da síndrome da apneia obstrutiva do sono}

Priscila Sequeira Dias'; Maria Helena de Araujo-Melo'; Denise Duprat Neves²; lucas Neves de Andrade Lemes33; Manuela Salvador Mosciaro"; SANDro Bedoya ${ }^{4}$

\section{A}

\begin{abstract}
Objective: To correlate anatomical and functional changes of the oral cavity, pharynx and larynx to the severity of obstructive sleep apnea syndrome (OSAS). Methods: We conducted a cross-sectional study of 66 patients of both genders, aged between 21 and 59 years old with complaints of snoring and / or apnea. All underwent full clinical evaluation, including physical examination, nasolarybgoscopy and polisonography. We classified individuals into groups by the value of the apnea-hypopnea index $(\mathrm{AHI})$, calculated measures of association and analyzed differences by the Kruskal-Wallis and chi-square tests. Results: all patients with obesity type 2 had OSAS. We found a relationship between the uvula projection during nasoendoscopy and OSAS (OR: 4.9; p-value: 0.008; Cl: 1.25-22.9). In addition, there was a major strength of association between the circular shape of the pharynx and the presence of moderate or severe OSAS (OR: 9.4, p-value: 0.002), although the CI was wide (1.80-53.13). The septal deviation and lower turbinate hypertrophy were the most frequent nasal alterations, however unrelated to gravity. Nasal obstruction was four times more common in patients without daytime sleepiness. The other craniofacial anatomical changes were not predictors for the occurrence of OSAS. Conclusion: oral, pharyngeal and laryngeal disorders participate in the pathophysiology of OSAS. The completion of the endoscopic examination is of great value to the evaluation of these patients
\end{abstract}

Key words: Sleep Apnea, Obstructive. Snoring. Endoscopy. Polysomnography. Anatomic Variation. Airway Obstruction.

\section{INTRODUCTION}

$\mathrm{O}$ structive sleep apnea (OSAS) has impacts on quality of life and is a risk factor for heart, metabolic, neurological and perioperative diseases ${ }^{1}$. It is characterized by recurrent episodes of partial (hypopnea) or complete (apnea) obstruction of the upper airways (UA) produced during sleep despite respiratory efforts ${ }^{2}$.

The pathophysiology of OSAS is multifactorial, however evidence shows that UA muscle control is the result of a delicate balance between different forces of intraluminal pressure during inspiration, which leads to a negative transpharyngeal pressure gradient, and the extraluminal pressure forces derived from muscle contractions that contribute to opening of the pharynx. Factors such as vasomotor tone and mucosal adhesive forces seem to collaborate with UA narrowing or collapse ${ }^{3}$. This reduction or intermittent cessation of airflow would cause oxyhemoglobin desaturation and nocturnal awakenings, with the consequent excessive daytime sleepiness (EDS), fatigue and cognitive changes ${ }^{4}$.

OSAS is a common disease worldwide, found in both developed and developing countries ${ }^{5-7}$. The prevalence of this disease in adult men is approximately twice the prevalence in adult women ${ }^{6,8,9}$. It is speculated that this difference between genders is due to hormones, to body fat distribution, to UA anatomy and function, to neural breathing control mechanisms $\mathrm{s}^{5,10}$ and possibly to factors related to clinical presentation, which is less evident in women. On the other hand, there is an increased prevalence in people aged over 50 , especially in elderly ${ }^{11}$.

Studies have observed increased body weight and neck circumference as OSAS predictors ${ }^{12-14}$. Some craniofacial abnormalities such as hypoplasia of the maxillary or mandibular bone would also have a role in the cause of OSAS ${ }^{15}$. The increase in nasal resistance, on its turn, also needs to be investigated, although the direct relation with increased apnea-hypopnea index $(\mathrm{AHI})$ and

1. Serviço de Otorrinolaringologia do Hospital Universitário Gaffrée e Guinle, Universidade Federal do Estado do Rio de Janeiro (UNIRIO), RJ, Brasil; 2. Serviço de Pneumologia do Hospital Universitário Gaffrée e Guinle, Universidade Federal do Estado do Rio de Janeiro (UNIRIO), RJ, Brasil; 3. Serviço de Otorrinolaringologia do Hospital Universitário Pedro Ernesto, Universidade do Estado do Rio de Janeiro (UNIRIO), RJ, Brasil; 4. Instituto Nacional de Infectologia, Fundação Oswaldo Cruz (Fiocruz), RJ, Brasil. 
snoring is unclear ${ }^{16}$. It has been demonstrated that consumption of alcohol, smoking and gastroesophageal reflux predispose to OSAS ${ }^{17,18}$.

This study aims to identify larynx and pharynx anatomical and functional changes visible through endoscopy in patients with varying degrees of OSAS and correlate them with their gravity.

\section{METHODS}

We prospectively and sequentially studied 66 adult patients with sleep-related disorders referred for evaluation of possible OSAS at the Universidade Federal do Estado do Rio de Janeiro in 2013. The study was approved by the institution Ethics and Research Committee, Opinion number 37/2011, and obtained financial support from the Rio de Janeiro state government (FAPERJ). All participants signed a free and informed consent form (ICF).

Initially, each patient underwent a detailed interview and general physical examination, including anthropometric body measurements (height, weight and body mass index-BMI-calculation). Secondly, there were orofacial, nasopharyngoscopic and polysomnographic assessments.

We excluded subjects with alterations that could seriously impair breathing, such as oral cavity, nasal and laryngeal tumors, facial middle third malformations and individuals with BMl greater than or equal to $40 \mathrm{~kg} / \mathrm{m}^{2}$, since they represent a high-risk group for OSAS.

\section{Reliability of measurements}

The evaluations were conducted by two researchers trained before the study so as to standardize the measurement techniques used. In case of disagreement, a third examiner was consulted. The intra and interobserver agreement was evaluated for BMI, neck circumference and Mallampati classification on a test pilot of 16 patients. The Spearman correlation analysis was used to confirm intra and interobserver reliability.

\section{assessments \\ Nasopharyngoscopy and orofacial \\ Oropharyngoscopy evaluated the Mallampati} classification for the relationship between the tongue and the oral cavity ${ }^{9}$ and the Brodsky ${ }^{10}$ classification for tonsils. Video Nasolaryngoscopy was carried out with a zero degree flexible endoscope, without topical anesthesia or turbinates vasoconstriction, with the patient awake, sitting up straight, with the torso and head naturally positioned and looking forward. In this position we performed the following measurements: A) cervical circumference: measured by reference to a horizontal line at the half of the thyroid cartilage; B) Modified Mallampati score: during oropharyngoscopy, with the tongue inside the mouth in a relaxed position, classified as: Grade 1 - when the tonsillar pillars, soft palate and the uvula are visible; Grade 2 - when the soft palate and the uvula are visible; Grade 3 - where the soft palate and uvula base are visible and Grade 4 where the soft palate is not visible; $\mathrm{C}$ ) Brodsky classification: during oropharyngoscopy, observing the tonsils size and the degree of obstruction exercised by them in the oropharynx, classified as: Level 1 - the tonsils occupy $25 \%$ of the space between the tonsillar pillars; Grade 2 - they occupy 25\% to $50 \%$; Grade 3 - the tonsils occupy $50 \%$ to $70 \%$ of the space between the tonsillar pillars; and Grade 4 - they occupy $75 \%$ or more; D) Tonsilar Projection - considered positive when their posterior portion partially or completely occluded the pharyngeal lumen at endoscopy; E) Pharynx format - through nasoendoscopy we classified the pharynx format as if the anteroposterior diameter was the same as the laterolateral one, and elliptical if otherwise; F) Reflux Signs: we considered as indirect signs of reflux: edema and / or hyperemia of the arytenoids, and / or hyperemia of the interarytenoid region, and the presence of redundant mucosa in the interarytenoid region; G) Glossoepiglottic Complex Projection (GEC): During nasoendoscopy, the rear projection of the base of the tongue and / or epiglottis causes partial or complete obstruction of the larynx view; H) Uvula Projection: during nasoendoscopy, the uvula is prominent toward the pharynx lumen, whether touching the posterior pharyngeal wall or not.

\section{Scales and protocols used}

We used the Epworth Sleepiness Scale (ESS) to assess excessive daytime sleepiness (EDS), considering positive a score higher than 10 points, and the Stanford scale for snoring, classifying it as absent, mild, moderate and severe.

\section{Polysomnography (PSG)}

We used Polysomnography methods, instrumentation and analysis according to the criteria and definitions published by the American Academy of Sleep Medicine ${ }^{19}$, as well as the classification of the OSAS severity with the apneas and hypopneas index $(\mathrm{AHI})$ : $\mathrm{AHI}<5$ (primary snoring), AHI 5 to 14.9 (mild OSAS), AHI 15 to 29.9 (moderate OSAS) and AHIe"30 (severe OSAS).

\section{Statistical analysis}

Our statistical strategy was to determine which anthropometric orofacial variables could be correlated with OSAS and thus determine some kind of risk. The clinical variables of interest were gender, age, body mass index, neck circumference and the Epworth sleepiness scale. Different cut-off points were used in order to find some association with $\mathrm{AHI}$ in patients with OSAS (AHI > 5, > 10, $>15$, and $>30$ ). We calculated the frequency of nominal variables and the central and dispersion measures of continuous variables for the presentation of sample characteristics and the variables studied. Differences were evaluated by the Kruskal-Wallis test, and proportions, by 
the chi-square test, considering values significant when $p$ $<0.05$. The odds ratio (OR) and its confidence interval of $95 \%(95 \% \mathrm{Cl})$ were calculated to assess the association between binary variables.

\section{RESULTS}

The questionnaire response rate on the individual characteristics and habits (gender, smoking, alcohol consumption, age) during the first consultation was $100 \%$ (Table 1). Of the 66 participants, 39 (59.1\%) were male and $27(40.9 \%)$ female. The average age was 41.97 years (21 59; SD 10.7). Ninety-five percent of people defined themselves racially as brown. As for $\mathrm{BMI}, 81.8 \%$ of participants were overweight or obese. All participants with BMI corresponding to obesity type 2 (BMI between 35 and 39.9) had OSAS.

Although a significant proportion of patients were smokers and drank alcohol, we found no significant differences between these variables and the presence or absence of OSAS.

Table 2 shows the results of the association between oro-pharyngo-laryngeal anatomical changes and OSAS. The format of the pharynx (circular and elliptical) was not significantly associated with OSAS. However, when we compare the two extremes of gravity, low-grade (none or mild OSAS) with the high grade (moderate and severe OSAS), we found an important strength of association (OR 9.4; p-value 0.002), although with a wide IC (1.80-53.13). This distribution shows a proportional increment as the disease intensity increases (Figure 1). The uvula projection during nasoendoscopy examination was associated with the presence of OSAS (OR 4.9; p-value 0.008; CI 1.25-22.9). The other craniofacial anatomical changes were not predictors for the occurrence of OSAS.

\section{DISCUSSION}

The narrowing of the upper airways is an important contributing factor to the closure of the pharynx during sleep in OSA ${ }^{20}$. Patients with OSAS may have a spectrum of orofacial abnormalities, of both skeletal anatomy and soft tissues. These abnormalities can act synergistically and participate in the complex OSAS cause. We believe that soft tissue and skeletal features may display variability between ethnic groups and contribute to the prevalence and severity of OSAS. This question was raised long ago by our group, considering that since the nineteenth and twentieth centuries Brazilian culture has been directed to racial integration and miscegenation, a fact proven by studies of genetic markers that show that people of Brazil are, in their majority, racially mixed ${ }^{21}$.

Table 1 - Habits and socio-demographic characteristics of individuals with and without OSAS.

\begin{tabular}{|c|c|c|c|}
\hline Variable & $\begin{array}{l}\text { Without OSAS } \\
\begin{array}{c}\text { (18 cases) } \\
\mathrm{n}(\%)\end{array}\end{array}$ & $\begin{array}{c}\text { With OSAS } \\
\text { (48 cases) } \\
n(\%)\end{array}$ & $\begin{array}{l}\text { Total } \\
\text { n (\%) }\end{array}$ \\
\hline \multicolumn{4}{|l|}{ Sex } \\
\hline Male & 7 (38.9) & $32(66.7)$ & $39(59.1)$ \\
\hline Female & $11(61.1)$ & $16(33.3)$ & $27(40.9)$ \\
\hline \multicolumn{4}{|l|}{ BMI } \\
\hline Up to 24.9 & $6(33.3)$ & $6(12.5)$ & $12(18.2)$ \\
\hline $25-29.9$ & $7(38.9)$ & $20(41.7)$ & $27(40.9)$ \\
\hline $30-34.9$ & $5(27.8)$ & $16(33.3)$ & $21(31.8)$ \\
\hline $35-39.9$ & - & $6(12.5)$ & $6 \quad(9.1)$ \\
\hline \multicolumn{4}{|l|}{ Smoking } \\
\hline Smoker & $2(11.1)$ & $4 \quad(8.3)$ & $6(9.1)$ \\
\hline No-smoker & $14(77.8)$ & $37(77.1)$ & $51(77.3)$ \\
\hline Ex-smoker & $2(11.1)$ & 7 (14.6) & 9 (13.6) \\
\hline \multicolumn{4}{|l|}{ Age } \\
\hline $20-35$ & $10(55.6)$ & $11(22.9)$ & $21(31.8)$ \\
\hline $36-50$ & $6(33.3)$ & $20(41.7)$ & $26(39.4)$ \\
\hline$\geq 50$ & $2(11.1)$ & $17(35.4)$ & $19(28.8)$ \\
\hline \multicolumn{4}{|l|}{ Alcoholism } \\
\hline Don't drink & $5(27.8)$ & $22(47.8)$ & $27(42.2)$ \\
\hline$<300 \mathrm{~g} /$ day & $13(72.2)$ & $19(41.3)$ & $32(50.0)$ \\
\hline >300g/ day & - & $5(10.9)$ & $5(7.8)$ \\
\hline
\end{tabular}

Source: medical records of patients with sleep disorders, Hospital Universitário Gaffrée e Guinle, Universidade Federal do Estado do Rio de Janeiro (2013). 
Table 2 - Association between anatomical changes and OSAS. Odds Ratio adjusted by logistic regression, p-value and confidence interval.

\begin{tabular}{|c|c|c|c|c|c|c|c|}
\hline \multirow{2}{*}{$\begin{array}{l}\text { Variable } \\
\text { Pharynx }\end{array}$} & \multicolumn{2}{|c|}{$\begin{array}{c}\text { Without OSA } \\
\text { (18 cases) } \\
(n / \%)\end{array}$} & \multicolumn{2}{|c|}{$\begin{array}{c}\text { SOAs } \\
\text { (48 cases) } \\
\text { (n/\%) }\end{array}$} & \multirow[t]{2}{*}{ OR } & \multirow[t]{2}{*}{$p$-value } & \multirow[t]{2}{*}{ IC $95 \%$} \\
\hline & & & & & & & \\
\hline Circular & 3 & $(16,7)$ & 13 & $(27,1)$ & 1,85 & 0,379 & $0,41-11,5$ \\
\hline Elliptical & 15 & $(83,3)$ & 35 & $(72,9)$ & & & \\
\hline \multicolumn{8}{|l|}{ Tonsillar Projection } \\
\hline Yes & 2 & $(11,1)$ & 9 & $(18,8)$ & 1,84 & 0,45 & $0,32-19,26$ \\
\hline No & 16 & $(88,9)$ & 39 & $(81,3)$ & & & \\
\hline \multicolumn{8}{|l|}{ Projection Uvula } \\
\hline Yes & 4 & $(22,2)$ & 28 & $(58,3)$ & 4,9 & 0,008 & $1,25-22,9$ \\
\hline No & 14 & $(77,8)$ & 20 & $(41,7)$ & & & \\
\hline \multicolumn{8}{|l|}{ CGE Projection } \\
\hline Yes & 2 & $(11,1)$ & 13 & $(27,1)$ & 2,9 & 0,16 & $0,55-29,7$ \\
\hline No & 16 & $(88,9)$ & 35 & $(72,9)$ & & & \\
\hline \multicolumn{8}{|l|}{ Mallampati score * } \\
\hline Altered (classes 2, 3 and 4) & 15 & $(83,3)$ & 43 & $(89,6)$ & 1,72 & 0,48 & $0,23-10,05$ \\
\hline Normal (class 1) & 3 & $(16,7)$ & 5 & $(10,4)$ & & & \\
\hline \multicolumn{8}{|l|}{ Brodsky rating ** } \\
\hline Classes 2, 3 and 4 & 6 & $(33,3)$ & 16 & $(33,3)$ & 1,00 & 1,0 & $0,28-3,87$ \\
\hline Classes 0 and 1 & 12 & $(66,7)$ & 32 & $(66,7)$ & & & \\
\hline
\end{tabular}

Source: medical records of patients with sleep disorders, Hospital Universitário Gaffrée e Guinle, Universidade Federal do Estado do Rio de Janeiro (2013).

Although we have not explored in detail other possible risk factors in addition to gender, BMI and age, our hypothesis is that with a simple routine endoscopy examination, checking anatomical alterations and measuring orofacial soft tissue changes, one could identify groups at higher risk for OSAS. It is logical to expect that in the future, to accomplish this, we need to prepare studies with larger samples and better define the groups to be studied, including control ones.

Among the anatomical parameters evaluated in this study, the pharyngeal circular shape was associated with more severe clinical forms of OSAS, possibly accounting

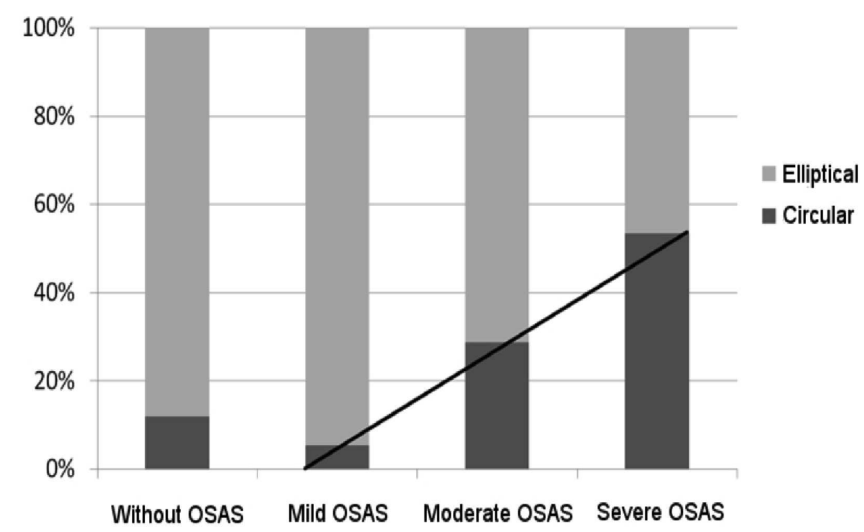

Figure 1 - Distribution of the pharynx format (circular and elliptical) in patients with OSAS. for a worse progression. We also found an association between the posterior projection of the uvula and OSAS. This leads to believe that some orofacial anatomic changes can be related to the severity and prognosis of OSAS. We know that the physiological shape of the pharynx is elliptical, with a wider laterolateral diameter. With the evolution of the disease the pharynx initially assumes a circular shape and, in later stages, once again becomes elliptical, but with a wider anteroposterior diameter due to hypertrophy of the pharyngeal lateral muscles. Unfortunately, however, we can not say that it is a true causal association, nor consider it a spurious one, mainly due to the small number of participants and the cofactors that were not considered in the analysis. Still, it is the starting point toward our hypotheses and this simple result leads to consider the possibility of defining high-risk groups for OSAS. Although the evaluated nasal parameters were the goal of another work conducted by our group, we can say that, in our findings, the septal deviation and lower turbinate hypertrophy were the most frequent nasal alterations, however unrelated to gravity. Nasal obstruction was four times more common in patients without daytime sleepiness.

We are aware of the limited scientific production when compared to studies in other countries, which hampers results comparisons. This is not proportionate to the impact of this condition. One study alarmingly showed that the prevalence of OSAS in São Paulo was around 30\%?. Unfortunately, we did not find in the national literature more data on the prevalence of OSAS in other Brazil regions 
to confirm these results. Some problems are related to the low amount of epidemiological studies on OSAS in Brazil, and perhaps the most important is the low supply of diagnostic services and specialized treatment, especially in the public system. Compared with data from foreign studies, Young et al. ${ }^{8}$ found in the American population prevalence of OSAS is $4 \%$ in men and $2 \%$ in women.

Most people with OSAS seek medical attention mainly due to snoring and daytime sleepiness, but we know that this syndrome also causes other effects in the body. OSAS is one of the major causes of morbidity and mortality worldwide and is responsible for an important part for the loss of DALYs (Disability Adjusted Life-Years). The DALY is a health measure that extends the concept of potential years of life lost due to premature death to include equivalent years of "healthy living" in less healthy states of life, generally referred to as "disability" 19 . OSAS substantially increases health systems economic costs. People with OSAS often seek more health services than individuals without it because of its association with daytime sleepiness, poor concentration and neuropsychological dysfunction ${ }^{22,23}$ and cardiovascular diseases (high blood pressure) ${ }^{24}$, using more resources.

The behavior of OSAS in the different groups configures a challenge to be overcome. Being a multifactorial disease, we know that its prevalence suffer modifications depending on the population studied. It is known that the proportion of cases with OSAS is greater in men and postmenopausal women without hormone replacement therapy as compared with premenopausal women or postmenopausal women who take hormone replacement ${ }^{11}$. Similarly, this prevalence tends to increase in older and more obese people, and in individuals with greater neck circumference ${ }^{14}$. The great variability of anatomical features in populations and the participation of numerous risk factors acting synergistically in the pathophysiology of OSAS become an obstacle to obtain concrete and reliable data. Ancoli-Israel et al. ${ }^{25}$ found a prevalence of OSAS in California of $24 \%$, in a study population composed only of elderly, in contrast with the aforementioned $2-4 \%$ in the US general population ${ }^{8}$. On the other extreme, in studies in the pediatric population, this prevalence drops to $0.7-3 \%$ and is closely related to the presence of adenoid and tonsil hypertrophy ${ }^{26}$. With regard to ethnicity, Scharf..$^{27}$ showed that the prevalence and severity of OSAS in African and Asian populations are higher than in Caucasian ones.

All these discrepancies motivate the need to carry out studies detailed in terms of prevalence and associated risk factors, including analysis of anatomical features. We believe that the endoscopic examination is an important step in the evaluation of patients with OSAS that cannot be waived, which may be critical to defining OSAS risk groups.

\title{
R E S U M O
}

\begin{abstract}
Objetivo: correlacionar alterações anatômicas e funcionais de cavidade oral, faringe e laringe com a gravidade da síndrome da apneia obstrutiva do sono (SAOS). Métodos: estudo transversal com 66 pacientes de ambos os sexos, com idade entre 21 e 59 anos e queixas de roncos elou apneia. Todos passaram por avaliação clínica otorrinolaringológica completa incluindo exame físico, nasolaringofibroscopia epolissonografia noturna. Foram classificados em grupos pelo valor do índice de apneia-hipopneia (IAH), calculadas medidas de associação e analisadas diferenças pelo teste Kruskal-Wallis e do $c^{2}$. Resultados: todos os pacientes com obesidade tipo 2 avaliados eram portadores de SAOS. Foi observada relação entre a projeção de úvula durante o exame fibronasoendoscopico e a SAOS (OR:4,9; p-valor: 0.008; IC: 1.25-22.9). Além disso, notou-se uma importante força de associação entre o formato circular da faringe e a presença de SAOS moderado ou grave (OR: 9,4, p-valor: 0,002), embora o IC seja amplo (1.80-53.13). O desvio septal e a hipertrofia de concha inferior foram as alterações nasais mais frequentes, porém sem relação com a gravidade. A obstrução nasal foi quatro vezes mais comum nos pacientes sem sonolência diurna. As demais alterações anatômicas craniofaciais não se mostraram preditoras para a ocorrência de SAOS. Conclusão: concluímos que alterações orais, faríngeas e laríngeas participam da fisiopatologia da SAOS. A realização do exame endoscópico é de grande valia para a avaliação destes pacientes.
\end{abstract}

Descritores: Apneia do Sono Tipo Obstrutiva. Ronco. Endoscopia. Polissonografia. Variação Anatômica. Obstrução das Vias Respiratórias.

\section{REFERENCES}

1. Park JG, Ramar K, Olson RJ. Updates on definition, consequences, and management of obstructive sleep apnea. Mayo Clin Proc. 2011;86(6):549-54; quiz 554-5.

2. Badr MS. Pathophysiology of upper airway obstruction during sleep. Clin Chest Med. 1998;19(1):21-32.
3. Haddad FL, Vidigal Tde A, Mello-Fujita L, Cintra FD, Gregório LC Tufik $S$, et al. The influence of nasal abnormalities in adherence to continuous positive airway pressure device therapy in obstructive sleep apneia patients. Sleep Breath. 2013;17(4):1201-7.

4. Epstein LJ, Kristo D, Strollo PJ Jr, Friedman N, Malhotra A, Patil SP, et al. Clinical guideline for the evaluation, management and longterm care of obstructive sleep apnea in adults. J Clin Sleep Med. 2009;5(3):263-76. 
5. Ip MS, Lam B, Tang LC, Lauder IJ, Ip TY, Lam WK. A community study of sleep-disordered breathing in middle-aged Chinese women in Hong Kong: prevalence and gender difference. Chest. 2004;125(1):127-34.

6. Udwadia ZF, Doshi AV, Lonkar SG, Singh CI. Prevalence of sleepdisordered breathing and sleep apnea in middle-aged urban Indian men. Am J Respir Crit Care Med. 2004;169(2):168-73.

7. Tufik S, Santos-Silva R, Taddei JA, Bittencourt LR. Obstructive sleep apnea syndrome in the São Paulo Epidemiologic Sleep Study. Sleep Med. 2010;11(5):441-6.

8. Young T, Palta M, Dempsey J, Skatrud J, Weber S, Badr S. The occurrence of sleep-disordered breathing among middle-aged adults. N Engl J Med. 1993;328(17):1230-5.

9. Kim J, In K, Kim J, You S, Kang K, Shim J, et al. Prevalence of sleepdisordered breathing in middle-aged Korean men and women. Am J Respir Crit Care Med. 2004;170(10):1108-13.

10. Young T, Hutton R, Finn L, Badr S, Palta M. The gender bias in sleep apnea diagnosis. Are women missed because they have different symptoms? Arch Intern Med. 1996;156(21):2445-51.

11. Bixler EO, Vgontzas AN, Ten Have T, Tyson K, Kales A. Effects of age on sleep apnea in men: I. Prevalence and severity. Am J Respir Crit Care Med. 1998;157(1):144-8.

12. Davies RJ, Ali NJ, Strading JR. Neck circumference and other clinical features in the diagnosis of the obstructive sleep apnea syndrome. Thorax. 1992;47(2):101-5.

13. Hoffstein V, Szalai JP. Preditive value of clinical features in diagnosing obstructive sleep apnea. Sleep. 1993;16(2):118-22.

14. Kushida CA, Efron B, Guilleminault C. A predictive morphometric model for the obstructive sleep apnea syndrome. Ann intern Med. 1997;127(8 Pt 1):581-7.

15. Tsai WH, Remmers JE, Brant R, Flemons WW, Davies J, Macarthur C. A decision rule for diagnosis testing in obstructive sleep apnea. Am J Respir Crit Care Med. 2003;167(10):1427-32.

16. Metes A, Cole P, Hoffstein V, Miljeteig H. Nasal airway dilation and obstructed breathing in sleep. Laryngoscope. 1992;102(9):10535.

17. Khoo SM, Tan WC, Ng TP, Ho CH. Risk factors associated with habitual snoring and sleep-disordered breathing in a multi-ethnic Asian population: a population-besed study. Respir Med. 2004;98(6):557-66.
18. Xiao YL, Liu FQ, Li J, Lv JT, Lin JK, Wen WP, et al. Gastroesophageal and laryngopharyngeal reflux profiles in patients with obstructive sleep apnea/hipopnea syndrome as determined by combined multichannel intraluminal impedance-pH monitoring. Neurogastroenterol Motil. 2012;24(6):e258-65.

19. Murray CJ. Quantifying the burden of disease: the technical basis for disability-adjusted life years. Bull World Health Organ. 1994;72(3):429-45.

20. Isono S, Remmers JE, Tanaka A, Sho Y, Sato J, Nishino T. Anatomy of pharynx in patients with obstructive sleep apnea and in normal subjects. J Appl Physiol. 1997;82(4):1319-26.

21. Santos RV, Maio MC. Race, genomics, identities and politics in contemporary Brazil. Crit Anthropol. 2004;24(4):347-78.

22. Engleman HM, Douglas NJ. Sleep. 4: Sleepiness, cognitive function, and quality of life in obstructive sleep apnoea/hypopnoea syndrome. Thorax. 2004;59(7):618-22.

23. Naëgelé $B$, Thouvard $V$, Pépin $J L$, Lévy $P$, Bonnet $C$, Perret JE, et al. Deficits of cognitive executive functions in patients with sleep apnea syndrome. Sleep. 1995;18(1):43-52.

24. Arzt M, Young T, Finn L, Skatrud JB, Bradley TD. Association of sleep-disordered breathing and the occurrence of stroke. Am J Respir Crit Care Med. 2005;172(11):1447-51.

25. Ancoli-Israel S, Kripke DF, Klauber MR, Mason WJ, Fell R, Kaplan O. Sleep-disordered breathing in community-dwelling elderly. Sleep. 1991;14(6):486-95.

26. Brunetti L, Rana S, Lospalluti ML, Pietrafesa A, Francavilla R, Fanelli $M$, et al. Prevalence of obstructive sleep apnea in a cohort of 1,207 children of southern Italy. Chest. 2001;120(6):1930-5.

27. Scharf SM, Seiden L, DeMore J, Carter-Pokras O. Racial differences in clinical presentation of patients with sleep-disordered breathing. Sleep Breath. 2004;8(4):173-83.

Received: 10/10/2014

Accepted for publication: 30/12/2014

Conflict of interest: none.

Source of funding: none.

Mailing address:

Priscilla Dias Sequeira

E-mail: prisdias@gmail.com 